AGORA International Journal of Juridical Sciences, www.juridicaljournal.univagora.ro ISSN 1843-570X, E-ISSN 2067-7677

No. 4 (2014), pp. 53-57

\title{
ABUSIVE CLAUSES IN INSURANCES DOMAIN
}

\section{O. E. Gălăţeanu}

\section{Oana Elena Gălățeanu}

Ph.D. Lecturer, Faculty of Juridical, Social and Political Sciences, Juridical Sciences Department "Dunarea de Jos" University, Galati, Romania

*Correspondence: Oana Elena Gălăţeanu, “Dunarea de Jos” University, 111 Domneasca Street, Postal Code 800201, Galati, Romania

E-mail: Oana.Galateanu@ugal.ro

\section{Abstract:}

The occurrence and development of some specialised domains in selling off products and in providing services have generated also new forms of contracts, like adhesion contracts and typical contracts. Through their specificity, they lead to the occurrence of an imbalance between the services provided by the contracting parties, not in favour of the consumer or of the client, allowing the occurrence of abusive contractual clauses. Such clauses can occur also in the contracts concluded in the insurances domain, contracts that have their character of adhesion as a specificity element, the professional insurer being the one who establishes the clauses and the insured client adheres or not to them, not being able to negotiate.

In this paper there are presented some clauses from the contracts concluded in insurances area that can be considered abusive.

\section{Keywords: abusive clauses, clients, insured, insurers}

\section{Introductions}

Law no.193/2000 regarding abusive clauses from the contracts concluded between professionals and consumers, republished, defines as abusive that clause not directly negotiated with the consumer if, through it or along other provisions from the contract, generates a significant imbalance between the rights and obligations of the parties, on contrary to the consumer's good faith and interest.

The same text of the law evidences three elements characteristic to an abusive clause, namely:

1. The clause was not directly negotiated with the consumer. It is supposed that it is not negotiated that clause that does not allow the consumer to influence its nature, to change or remove it, as there are pre-created contracts. In the doctrine, it was highlighted that accepting a clause does not mean its negotiation;

2. The rule of good faith is not complied with, rule that implies removing any action or omission that might harm the co-contractor. Law no. 193/2000 refers to good faith in general, reason for which the professional must have acted with the intent to prejudice the consumer, in bad faith. It is considered that it is in unconformity with the good faith the inclusion of a clause that produces an important imbalance not in favour of the consumer;

3. To exist an important, significant imbalance between the rights and responsibilities of the parties. The criterion of assessing this imbalance is a real one, analysed in report to the circumstances corresponding to every contract concluded.

Also from Law no. 193/2000 we conclude that the provisions regarding the abusive clauses are applicable to those juridical reports that take place between consumers and traders. Art.1, paragraph 1 of this law, provides that any contract concluded between traders and consumers for the sale of goods or for providing services will include clear contractual clauses, in no uncertain 


\section{ABUSIVE CLAUSES IN INSURANCES DOMAIN}

terms, for their understanding not being necessary specialty knowledge, and in paragraph 3 of art. 1 of the law it is forbidden for traders to include abusive clauses in the contracts which they conclude with the consumers. This law comprises also an annex where there are exemplified contractual clauses considered abusive, the legislator not limiting the area of these clauses to only the ones exemplified.

From the provisions of law no. 193/2000, we find that all contracts concluded between traders and consumers can be the object of the above, all the more adhesion or pre-formulated contracts. A type of adhesion contract is the insurance contract, that is a contract where the clauses are established by one of the parties, without any possibility for the other party to discuss them, but only to accept them by concluding them, or not accepting them by refusing their conclusion, no matter if is has as object the goods, civil liability or persons. In the case of these contracts, the insurer, as professional, establishes the clauses of the contracts that are going to be concluded with the potential insured clients. These contractual clauses issued by the insurer have the general purpose to shield the insurance company from paying indemnifications, following to being produced some events that cannot be controlled. From this point of view, many exclusion clauses are absolutely natural, but others are unclear, excessive or deceitful and due to this reason they should be investigated and analysed. There is a series of exclusion from insurances that already breach the legal norms and they can be considered as being abusive clauses, not being able to be directly negotiated with the insured client and not being in his/her favour, as well as being contrary to good faith.

Out of the clauses exemplified in the annex of Law no. 193/2000 as being abusive, we consider that the following could be also encountered in the insurance contracts:

a) Provisions that give the exclusive right to the professional to interpret the contractual clauses. Regarding these provisions, we could give as example the medical malpraxis insurance contract where there are met contractual clauses through which the insurer's obligation to give indemnifications is removed (excluded). In practice, one of the obligations expressly included in the contract that devolves upon the insured (doctor in this case) is the one to refrain from any admission towards third parties - inclusively towards the prejudiced person - regarding his/her responsibility in producing the prejudice / event that could lead to granting the indemnity. In case he/she would breach this obligation, that is he/she would practically admit his/her error or fault in producing the undesired event, the insured doctor would not receive any indemnity from the insurer, even if he/she would comply with all other contractual obligations and first of all, with the basic obligation to pay up to date the insurance premiums. We consider that this condition expressly imposed by the insurer is an abnormal condition in the least, due to the fact that this insurance is concluded so that the insured person to be protected for the eventual case where by his/her error or fault, he/she committed a malpraxis act. Due to this reason we believe that this contractual clause is abusive and illegal;

b) Provisions that limit or cancel the consumer's right to demand indemnifications in case the professional does not comply with his/her contractual obligations.

In our opinion, being an adhesion contract, unfortunately, the professionals - respectively the insurers - do not always explain to the insured client all his/her rights and revert to such practices with intent, just for protecting his/her own interests, this not being in favour of the insured person who maybe would not conclude such contracts with the respective insurance companies, being totally informed.

For example, it cannot be accepted the insurer's demand of cancelling the contract, on the grounds of own fault at concluding the insurance contract. ${ }^{1}$

c) Provisions that restrict or cancel the client's right to denounce or to unilaterally cancel the contract, in cases when the professional either unilaterally changed the contractual clauses, or

\footnotetext{
${ }^{1}$ This fact was provided also by the judiciary practice in the domain; see also Alba-Iulia Court of Appeal, Commercial Division, Decision no. 242 as of $1^{\text {st }}$ October 2004, Manuela Tărăbaş, Mădălina Constantin, Insurances. Judiciary practice compilation, C.H. Beck Publishing House, Bucharest 2009, pp. 100-102.
} 


\section{O. E. Gălățeanu}

he/she did not fulfil his/her obligations or he/she imposed to the client clauses regarding payment of a fixed amount (in case of unilateral denunciation);

d) Clauses that exclude or limit the legal responsibility of the professional in case of consumer's injury or death, as the result of an action or omission of the trader regarding the usage of the products or services.

Such an abusive clause can be met at the insurance policies for houses sold by certain insurance companies from our country that infringe upon the provisions from the Civil Code. We refer to those contracts concluded by the authorized insurers where, under "exclusions" chapter, there are included also the claims of indemnifications from the husband, wife or relatives of the insured, even if the beneficiaries are not specified in the contract. This fact is not natural if we have in view that fact that the insurance policies for houses cover also serious risks like earthquakes or landslide, events that increase the risk of occurrence of the death of the insured person during their occurrence. In such cases, by applying the clause stipulated in the contract, the insurance company will not pay indemnifications to the family of the insured which deceased, even if the insured paid and the insurance company received the respective insurance premiums. If we consider the provisions of art.2230 Civil Code regarding the insurances for persons, that provide that "in case of the insured death, in case no beneficiary was designated, the insurance indemnity is part of the deceased's estate, returning to the inheritors of the insured", then we can conclude that this clause is abusive, since it limits the right to inherit.

In our opinion, abusive clause is also the clause from some insurance contracts for medical malpraxis which removes the obligation of the insurer vis-à-vis indemnification claims formulated by third parties, other then the patients, claims whose coverage is excluded by the insurers.

We do not consider rightful this clause mentioned above, due to the fact that the patient's family or next of kin have the right to claim the indemnifications in the regrettable case of patient's decease. Due to this reason, we believe that the health care professionals should not accept insurer's liability as clause of exclusion, not being rightful or valid at all.

e) Clauses that give the professional the right to transfer the contractual obligations into the responsibility of a third party (agent, proxy), without client's agreement, if this transfer helps at reducing the guarantees or other liabilities towards the clients.

In practice, in the case when the insurance contract is concluded with the help of an insurance agent who cashes also the insurance premiums, having the obligation to handover them, along with the documents of the insurance company, within a certain period of time, in case he/she does not comply with the due dates established and the risk insured is produced in the mean time, the insurer will have to comply with the obligation of paying the indemnification towards the client insured, being able to revert to recourse action against the agent. The insurer will not be able to refuse to pay the indemnification towards the insured client due to the fact that it did not receive the rightful insurance premiums. ${ }^{2}$

f) The clauses that provide that the price of the products is established at the moment of delivery or that allow to the sellers of products or to the suppliers of services the right to increase the prices, without giving the right to cancel the contract to the clients, in case the final price is too high as compared to the price convened at the moment of concluding the contract, in both cases.

We consider that these provisions could be associated in the insurances domain with the situation when the insurer, although it concluded a contract of insurance of goods through which it was established a certain value to the insurance premium and to the amount insured, after being produced the insured risk, it decides to decrease the value of the indemnification which was committed through the contract, considering that the goods present a degree of usage which is higher than the one provided in the policy. This was considered although the insurance premiums were paid according to the degree of usage provided in the contract, thus being

\footnotetext{
${ }^{2}$ Bacău Court of Appeal, Commercial decision no. 69 as of 11th October 2005, Manuela Tărăbaş, Mădălina Constantin, Insurances. Judiciary practice compilation, C.H. Beck Publishing House, Bucharest 2009, pp. 78-79
} 


\section{ABUSIVE CLAUSES IN INSURANCES DOMAIN}

accepted by it. In our opinion, this action of the insurer can be appreciated as being abusive and thus the insured client is entitled to refer the case to the competent court for rejecting these reasons and for forcing the insurer to comply with his/her responsibilities as committed through the contract which was validly concluded. ${ }^{3}$

According to the civil provisions, nobody can exercise any right with the purpose of being detrimental to or to prejudice another person excessively, unreasonably and contrary to good faith, without being penalised for reasons of abusive exercise of rights (art. 15 Civil Code). In the juridical literature, it is considered that the penalty applied to the abusive clauses is the nullity of the contract included by it. Actually, the penalty of nullity is also based on the legal provisions comprised in art.1 paragraph 1 of Law no. 193/2000, according to which any contract must include clauses which are clear, in no uncertain terms and easy to understand for all parties. Actually, the nullity has as basis also incompliance with the basic condition for the validity of a contract regarding its cause which must be licit and moral, due to the fact that an abusive clause has as grounds bad faith at concluding the contract.

Having in view the fact that through inserting an abusive clause, only a part of the professional's will is corrupted by the bad faith at concluding the contract, breaching the legal condition regarding the cause affects only a part of the contract, respectively the abusive clause. This partial nullity will demolish only one part of the contract concluded, respectively the clause considered as being abusive and the contract remains partially valid. In case the abusive clauses do not produce effects against the consumer client, then, with his/her agreement, the contract will continue to produce effects, if the contract can be continued following to eliminating the clauses under discussion. In case the contract cannot produce effects following to eliminating the abusive clauses, then the consumer has the right to pretend its cancellation, according to art. 7 of Law no. 193/2000, case when he/she is entitled to obtain indemnifications also, the professional's responsibility being a liability in tort.

Both in practice and in the doctrine there are numerous discussions based on the penalty of the abusive clauses motivated by the reality that the law regarding these clauses does not refer to a juridical procedure through which to be removed the effects of the abusive clauses, as it is provided by other legislations, like the French or Quebec region legislations.

The existence of the abusive clauses must be proved by the one who invokes it, respectively by the consumer / client, according to the civil provisions in force, through evidences provided by the Civil Procedure Code; Law no. 193/2000 does not comprise special provisions in the domain. The object of the evidence can be represented by any of the three conditions necessary to the existence of such a clause: lack of negotiation, lack of good faith, the presence of a significant imbalance.

In case of adhesion contracts - like the insurance contract - that comprise abusive clauses, the law authorizes certain control authorities to notify the court from the professional's domicile or headquarters and to request his/her obligation to change the contracts under developments, by removing the abusive clauses, as it is provided by art.12 of Law no.193/2000. These authorities are represented, according to art.8 of the law, by the National Authority for Consumers' Protection representatives, as well as by the authorized specialists of other public administration authorities, according to their competencies. Besides them, the consumers prejudiced through the respective contracts have the right to address to the court.

The court cannot change itself the clauses considered abusive from the contract, but it will be able to force the professional to change all adhesion contracts in development, when there is observed such a clause exists in the contract, as well as to eliminate the abusive clauses from the pre-formulated contracts which are meant for use in the professional activity, as it is provided by art.13 paragraph (1) of the law to which we refer to.

In case the court observes that there are no abusive clauses in the contract, it will cancel the report issued by the official examiner according to the law.

\footnotetext{
${ }^{3}$ See High Court of Cassation and Justice, Commercial Division, Decision no. 2408 as of 18th April 2003, www.scj.ro
} 


\section{Conclusions}

In the insurance contract there is a series of exclusion from insurances that already breach the legal norms and they can be considered as being abusive clauses, not being able to be directly negotiated with the insured client and not being in his/her favour, as well as being contrary to good faith.

It would be desired to be brought modifications to the actual Romanian law regarding the abusive clauses for clarifying these aspects that refer to the above mentioned juridical mechanism to removed the effects of this clauses.

\section{Bibliography}

- N. Gheorghe, C. Spasici, D.S. Arjoca, Consumption Law, Hamangiu Publishing House, Bucharest, 2012

- M. Tărăbaş., M.Constantin., Insurances. Juridicary practice compillation, C.H. Beck Publishing House, Bucharest, 2009

- www.scj.ro 